\title{
Emancipation of Emma Woodhouse Explored: An Analysis of Jane Austen's Emma
}

\author{
Dr. B. Janaki \\ Assistant Professor of English, Kingdom University, Kingdom of Bahrain \\ sharewithjanaki@gmail.com
}

\begin{abstract}
The aim of this paper is to explore the characteristic charisma of Jane Austen's heroine, Emma Woodhouse who is a social snob and over-sure of her own judgment. With reference to Emma's nature, Bradley (1851-1935) points out, "She has a generous nature. She is self-confident, and she likes to be first; but she is not vain. She is faultless in her relations with her father; and, though she will not take advice from Knightley, her readiness to take reproof and to make amends for her errors is more than magnanimous." In Stovel (1941-2007)'s reading of the novel all oppositions finally dissolve as Emma's education is completed and her 'desire to be herself, her desire for Knightley, and her desire to be good all...coincide' in such a way that a vision of 'harmony, not sacrifice or division, reigns.'
\end{abstract}

Keywords: Jane Austen, Emma, Knightley, judgement and snob.

\section{INTRODUCTION}

Jane Austen, in Emma, presents a heroine, Emma Woodhouse who is a social snob, over sure of her own judgment, and so has a propensity for match-making. Emma who can 'esteem, loathe, praise, censure, grieve, rejoice- but she cannot feel like anyone else in the world ${ }^{11}$ is described in the following way:

Emma Woodhouse, handsome, clever, and rich, with a comfortable home and happy disposition, seemed to unite some of the best blessings of existence; and had lived nearly twenty-one years in the world with very little to distress or vex her.... ${ }^{2}$

We must agree with Howells (1837-1920) that 'it took supreme courage to portray a girl, meant to win and keep the reader's fancy, with the, characteristics frankly ascribed to Emma Woodhouse...An officious and self-confident girl, even if pretty, is not usually one take the fancy, and yet Emma takes the fancy. ${ }^{3}$

Emma prides herself on her successful matchmaking, and declares that, without her own intervention, the attachment between her governess, Miss Taylor and Mr. Weston who 'was a native of Highbury, and born of a respectable family, which for the last two or three generations had been rising into gentility and property, ${ }^{4}$ might not have come to anything after all. The departure of Miss Taylor leaves Emma intellectually solitary and then her days are devoted to the care of her father and enlivened by congenial associates of her own age. Emma's boredom is relieved by a new and temporarily absorbing interest when she meets Harriet Smith, a pretty young woman of unknown parentage, who has been brought up at Mrs. Goddard's school in Highbury.

1 Marvin Mudrick, Jane Austen Irony as Defense and Discovery (Princeton: Princeton University Press, 1952) 200.

2 Jane Austen, Emma (New Delhi: Surjeet Publications, 2004) 5.

3 William Dean Howells, “Her Most Boldly Imagined Heroine," \ane Austen Emma ed., David Lodge (London: Macmillan, 1968) 62-63.

4 Emma 12.

www.arjonline.org

Page 1 
Emma decides to make Harriet a perfect wife for Mr. Elton. Emma decides to patronize and 'improve' Harriet:

Encouragement should be given...The acquaintance she had already formed were unworthy of her ... and introduce her into good society; she would form her opinions and her manners. It would be an interesting, and certainly, a very kind undertaking; highly becoming her own situation in life, her leisure, and powers. ${ }^{5}$

Consequently, Emma sets herself to systematically destroy the respect and admiration felt by Harriet for Robert Martin as Emma thinks that marriage with Robert Martin may limit Harriet's future to a social circle for which Emma has no desire. In the following conversation between Emma and Harriet, on the same issue, Emma ruthlessly pursues this objective:

'I want to see you permanently well connected- and to that end it will be advisable to have as few odd acquaintances as may be; and, therefore, I say that if you should still be in this country when Mr. Martin marries, I wish you may not be drawn in, by your intimacy with the sisters, to be acquainted with the wife, who will probably be some mere farmer's daughter, without education.'

'To be sure. Yes. ...However, I do not mean to set up my opinion against your's- and I am sure I shall not wish for the acquaintance of his wife. ${ }^{6}$

Harriet's reply suggests that she has already inwardly bidden the Martins farewell in obedience to Emma's superior judgement. Emma's methods are unfair, not only to the absent Martin and the defenseless, slow-witted Harriet, but to herself. Her arrogant self-will exists side by side with a compassionate, charitable spirit that includes the destitute as well as impoverished respectable folk of Highbury.

Meanwhile, Harriet receives a letter from Robert Martin containing 'a direct proposal of marriage.7 Emma, having Mr. Elton reserved for Harriet, persuades Harriet to send a letter of refusal to Robert Martin. In order to assuage her friend's disappointment, Emma assures her that Mr. Elton will be the right choice for Harriet. In the mean time, Mr. Knightley warns Emma, that, if she is going to try match-making for Harriet, she had better not consider Mr. Elton as Mr Knightley is sure that, "Elton is a very good sort of man, and a very respectable vicar of Highbury, but not at all likely to make an imprudent match. He knows the value of a good income as well as anybody. Elton may talk sentimentally. But he will act rationally." ${ }^{8}$ Despite her respect for Mr. Knightley's judgment, Emma is determined and persuades herself that 'Mr. Knightley did not make due allowance for the influence of a strong passion at war with all interested motives. ${ }^{9}$

When John Knightley, who, with his family, has come to visit the Woodhouses, points out to Emma that Mr. Elton "'seems to have a great deal of good-will towards you,"' ${ }^{10} \mathrm{Emma}$ ignores saying that they have been good friends. Her suspicions having been aroused, Emma is somewhat distressed to find herself riding home alone from the Westons' party with Mr Elton in the carriage. ConsequentlyMr Elton proposes Emma and the novelist reflects over the situation thus, "It was really so. Without scruple- without apology- without much apparent diffidence, Mr. Elton, the lover of Harriet, was professing himself her lover." ${ }^{11}$ It leaves Emma stunned when Mr. Elton insists "Every thing I have said or done, for many weeks past, has been with the sole view of marking my adoration

\begin{tabular}{ll}
\hline 5 & Emma 18-19. \\
6 & Emma 24. \\
7 & Emma 39. \\
8 & Emma 51. \\
9 & Emma 52. \\
10 & Emma 85. \\
11 & Emma 99
\end{tabular}

American Research Journal of English and Literature 
of yourself. You cannot really, seriously, doubt it."'12 Emma refuses saying, "I have seen you only as the admirer of my friend. In no other light could you have been more to me than a common acquaintance..."13 Her refusal is a sort of social snub as she has intended him to marry a wife whose claims to rank of any kind are obscure and uncertain.

Though progress has been made in the direction of self-knowledge, Emma is certainly not yet sufficiently self-aware and Lionell Trilling (1905-1975) says that "The extraordinary thing about Emma is that a consciousness is always at work in her, a sense of what she ought to be and do."14 Pondering over Harriet's disappointment, Emma resolves that 'Where the wound had been given, there must the cure be found if anywhere; and Emma felt that, till she saw her in the way of cure, there could be no true peace for herself.' 15 In other words, Emma is still determined to find Harriet a husband but decides not to be so 'active'16 in her schemes of promotion.

Emma feels a lively interest ever since she has heard of Frank Churchill's proposed visit to Highbury, who is the son of Mr. Weston through his first marriage. Frank is a handsome, high-spirited, aristocratic young man in whom Emma has been attracted enough to think that if she were to marry, he would be the very person to suit her in age, character and condition. Emma imagines him as a model of general information, conversational ease, and good manners but Mr. Knightley heatedly rejects the picture of a man of twenty-three setting up as "the king of his company"17 and opines that he would be an insufferable puppy.

Emma does not tolerate anyone whose accomplishments are superior to her own and so she is always willing to imagine a fault in Jane Fairfax, Miss Bates's niece whose praises sound perpetually and irritatingly in her ears. Jane Fairfax is an orphan, brought up by a Colonel and Mrs. Campbell, and she had been a close friend of their daughter; but the daughter had married a Mr. Dixon and gone to Ireland, where the Campbells are now joining her, and Jane is to stay in Highbury before looking for a post of governess. Jane Fairfax presents a challenge to Emma of what Harriet has never been capable. Jane is a rival in everything except birth and prospects.

When Frank visits Highbury and Emma shifts her attention from Mr. Elton to Mr. Frank Churchill. At this instance also, it is Knightley who gives the correct opinion on Frank promptly to Emma which she contradicts:

'My idea of him is, that he can adapt his conversation to the taste of everybody, and has the power as well as the wish of being universally agreeable. To you, he will talk of farming; to me, of drawing or music; and so on to everybody, having that general information on all subjects which will enable him to follow the lead, or take the lead, just as propriety may require, and to speak extremely well on each; that is my idea of him.'

'And mine,' said Mr. Knightley warmly, 'is, that if he turns out any thing like it, he will be the most insufferable fellow breathing! What! At three-and-twenty to be the king of his company-the great man- the practiced politician, who is to read everybody's character, and make everybody's talents conduce to the display of his own superiority... ${ }^{18}$

Meanwhile, Miss Bates discloses the information that Mr. Elton is betrothed to a Miss Augusta Hawkins of Bath. Mrs. Elton's tacit rivalry with Emma is clear from the time she enters Highbury as Mr. Elton's bride. Not only has

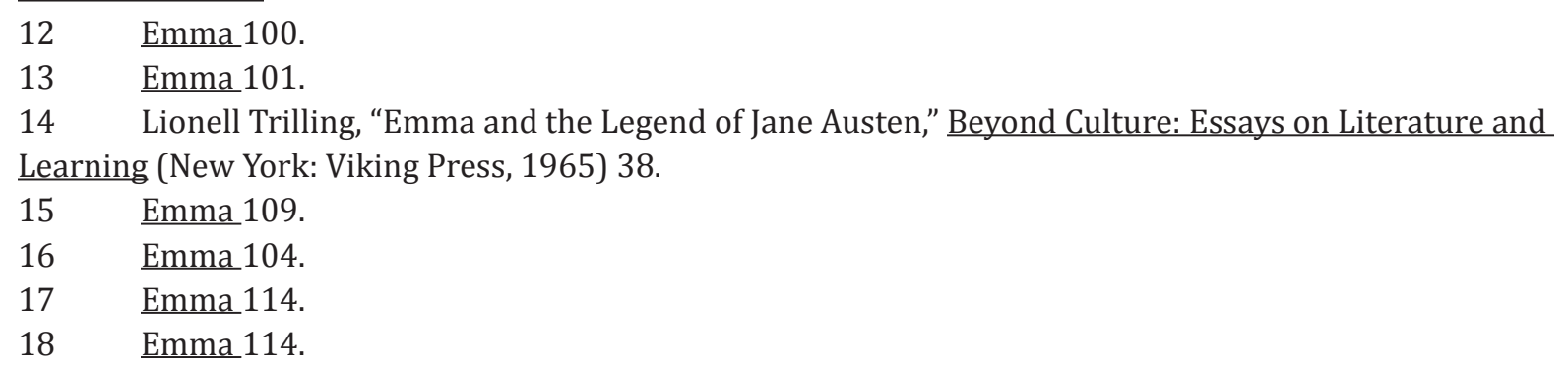


Mr. Elton met and married her a few weeks after his humiliating rejection by Emma, but Mrs Elton's eagerness to bring Jane Fairfax forward is at once an echo of Emma's own enthusiasms regarding Harriet Smith, and a reproach to Emma's neglect of Jane. Emma is disgusted and angry at Mrs. Elton's patronage of Jane and her anger becomes more when Mrs. Weston says that Mr. Knightley may have a more than ordinary interest in Jane Fairfax. Emma continues to object, and one of her protestations is, "My dear Mrs. Weston, do not take to matchmaking. You do it very ill. Jane Fairfax mistress of the Abbey!- Oh! No, no;- every feeling revolts. For his own sake I would not have him so mad a thing."'19

Then Emma's match-making eyes shift to Harriet who is now flustered and unhappy. For the first time, Emma thinks that an attachment between Frank Churchill and Harriet might be desirable and again plans to bring it into effect. Mr Knightley has been harbouring feelings of love for Emma but he does not reveal his love to her as he thinks she is in love with Frank. The following scene clearly reveals Mr. Knightley's divided feelings; his spontaneous response to Emma's act of penitence attests his happy recognition of the Emma he loves and he believes that she does not love him as she is interested in Frank.

Later, the news of the death of Mrs. Churchill, Frank's aunt, reaches Highbury, and Frank openly announces his secret engagement to Jane Fairfax. Emma is greatly disappointed and feels sorry that for the second time Harriet is hurt and rejected, she repents "Harriet, poor Harriet! Those were the words; in them lay the tormenting ideas which Emma could not get rid of, and which constituted the real misery of the business to her. ...Frank Churchill had behaved very ill."' 20 But Harriet is not moved as she is now interested in Mr Knightley. As Harriet enumerates her reasons for believing that Mr. Knightley cares for her, Emma finds herself more and more unable to control the agitation of her heart. The possibility of losing Mr. Knightley makes her realize her love for him and that Mr. Knightley must marry no one but herself. She makes Harriet understand that "Mr. Knightley is the last man in the world, who would intentionally give any woman the idea of his feeling for her more than he really does." 21

Emma feels sorry that she has taught Harriet to have the presumption to elevate her thoughts to Mr. Knightley instead of being content to marry a man of her own class like Robert Martin. Emma regrets for her flirtation with Frank Churchill, remembering how it would have pained Jane, and repents for her suspicion of an improper attachment between Jane and Mr. Dixon. At last Emma gets enlightenment:

With insufferable vanity had she believed herself in the secret of everybody's feelings; with unpardonable arrogance proposed to arrange everybody's destiny. She was proved to have been universally mistaken; and she had not quite done nothing- for she had done mischief. She had brought evil on Harriet, on herself, and she too much feared, on Mr. Knightley...22

In course of time, Harriet could retain her attachment with Martin who is now considered to be superior to Frank Churchill in Emma's opinion.

Mr. Knightley having received the news of Frank's engagement with Jane is filled with anxiety regarding Emma's reaction to the event. He believes that Emma really cares for Frank and he comes to offer her consolation to her as a true friend. Emma convinces Mr. Knightley that she has never loved Frank though she suspects an attachment between Harriet and Mr. Knightley. But finding Emma's affections disengaged, he could not help asking "Tell me, then, have I no chance of ever succeeding?" ${ }^{23}$ At this question, Emma feels dread of being awakened from what seems the happiest dream.

$19 \quad$ Emma 168.

20 Emma 302.

21 Emma 309.

22 Emma 310-11.

23 Emma 323.

American Research Journal of English and Literature 
Mr. Knightley, the novel's 'normative and exemplary figure, ${ }^{24}$ goes on to say that he cannot make speeches, as he might if he loved her less. "I have blamed you, and lectured you, and you have borne it as no other woman in England would have borne it." ${ }^{25}$ She must, she does, understand his feelings, and will return them if she can. Emma in turn rejoices that he has not mentioned Harriet, "While he spoke, Emma's mind was most busy, and, with all the wonderful velocity of thought, had been able ... to catch and comprehend the exact truth of the whole; ...that Harriet was nothing; that she was every thing herself; that what she had been saying relative to Harriet had all been taken as the language of her own feelings." ${ }^{26}$

Though Austen may have disliked pictures of perfection in her heroes and heroines, Mr Knightly came as near her ideal as possible, an ideal which she summed up in one of her letters as a person 'where grace and spirit are united to worth, where the manners are equal to the heart and understanding. ${ }^{27}$ With reference to Emma's nature, Bradley (1851-1935) points out, "She has a generous nature. She is self-confident, and she likes to be first; but she is not vain. She is faultless in her relations with her father; and, though she will not take advice from Knightley, her readiness to take reproof and to make amends for her errors is more than magnanimous." ${ }^{28}$ In Stovel (1941-2007)'s reading of the novel all oppositions finally dissolve as Emma's education is completed and her 'desire to be herself, her desire for Knightley, and her desire to be good all...coincide' in such a way that a vision of 'harmony, not sacrifice or division, reigns. ${ }^{29}$

\section{REFERENCES}

Austen, Jane. Emma New Delhi: Surjeet Publications, 2004.

Bradley, A. C. A MiscellanyLondon: Macmillan, 1929.

Chapman, R.W. ed., Jane Austen's LettersOxford, 1952.

Duckworth, Alistair M. The Improvement of the Estate: A Study of Jane Austen's Novels Baltimore, 1971.

Howells, William Dean. “Her Most Boldly Imagined Heroine," Jane Austen Emma ed., David Lodge. London: Macmillan, 1968.

Mudrick, Marvin. Jane Austen Irony as Defense and Discovery. Princeton: Princeton University Press, 1952.

Stovel, Bruce. introduction, Jane Austen’s Emma ed. David Lodge London: Macmillan, 1992.

Trilling, Lionell. "Emma and the Legend of Jane Austen," Beyond Culture: Essays on Literature and Learning New York: Viking Press, 1965.

24 Alistair M. Duckworth, The Improvement of the Estate: A Study of Jane Austen's Novels (Baltimore, 1971) 148.

$25 \quad$ Emma 323.

26 Emma 323.

27 R.W. Chapman, ed., Jane Austen's Letters (Oxford, 1952) 409.

28 A.C. Bradley, A Miscellany (London: Macmillan, 1929) 33.

29 Bruce Stovel, introduction, Jane Austen's Emma ed. David Lodge (London: Macmillan, 1992) 2.

Citation: Dr. B. Janaki, "Emancipation of Emma Woodhouse Explored: An Analysis of Jane Austen's Emma" American Research Journal of English and Literature, vol 3, no. 1, 2017, pp. 1-5.

Copyright (C) 2017 Dr. B. Janaki, This is an open access article distributed under the Creative Commons Attribution License, which permits unrestricted use, distribution, and reproduction in any medium, provided the original work is properly cited. 